\title{
The Social Construction of Bodily Injury
}

\section{Phil Bell}

Royal \& Sunalliance, Leadenhall Court, 1 Leadenhall Street, London EC3V 1PP, U.K.

E-mail: phil.bell@uk.royalsun.com

This paper looks at how changing social attitudes have influenced both the courts and lawmakers in relation to liability claims for bodily injury. It has a strong U.K. bias. The paper considers the impact on underwriters of various court rulings and the extent to which a compensation culture may exist in the U.K. It goes on to give examples of recent claims examples, particularly in the area of psychiatric illness and how U.K. courts have allowed a number of types of claim to succeed that at one time would have been unimaginable. Further examples demonstrate the extent to which claimants are now testing the boundaries of what courts will accept. The paper also looks at the growing problem with fraudulent claims and concludes with some ideas for how liability underwriters can combat these trends.

The Geneva Papers (2006) 31, 340 - 356. doi:10.1057/palgrave.gpp.2510077

Keywords: liability; injury; compensation; insurer; psychiatric; trigger

\section{Introduction}

In recent years, the U.K. has seen a sharp change in activity for claims arising from bodily injury. Undoubtedly, the attitude of the population has changed and with it comes the evolution of the tort system as the courts constantly adapt their way of thinking in line with society, and statutory liability is also updated as politicians strive to keep in tune with the electorate. This paper examines the trends in the U.K. and their impact on liability underwriters and provides some guidance on how to combat them.

\section{Background}

We live in a changing world where nothing ever seems to stay the same for very long. This can result in some very positive benefits for society, but for the liability underwriter, it invariably brings new problems and something new to worry about.

When I first became involved with the underwriting of liability insurance in the U.K., everything appeared to be quite straightforward: we paid claims for compensation to people who suffered bodily injury as a result of an act of negligence by the insured that caused an accident. We thought we knew where we stood, tort law evolved albeit slowly, bodily injury claims could take several years to settle but their cost was fairly predictable. Many people were reluctant to pursue claims if they were employment related, as it might have affected their job security and in any event, the legal system was perceived as bureaucratic, expensive and inaccessible to most people. We thought we understood our policy wordings and how they respond to claims, and the external environment was very calm - not a great deal changed.

How wrong we were. 
We have seen:

- levels of awards grow at a rate unimaginable 30 years ago;

- rapid strides forward in medical and scientific knowledge that have led to an increase in the establishment of causal links between an activity and harm;

- substantial changes in social outlooks: what was acceptable and tolerated 30 years ago is unacceptable today. What used to be regarded as an accident today results in the injured party looking for someone to blame;

- the expansion of liability laws as a result of legislation;

- the interpretation of liability by the courts has shifted substantially, generally as a consequence of the changing views of society;

- a significant growth in the propensity to claim, fuelled by the media and the availability of a range of products and services designed to improve access to justice;

- a desire for "justice" to be seen to be done, often appearing as more than just an entitlement to financial compensation; it is also about punishing the guilty party.

This has led to a diminishing appetite for liability insurance from many insurers in many markets, and this cannot be to the benefit of society, which relies upon insurance for the payment of compensation. It has become very difficult for insurers, who are, after all, commercial organizations, to write this business successfully. A number have retreated or even withdrawn capacity. However, I do believe this business can be written successfully as part of a range of covers offered to customers. For me, the crucial issue is to learn from the past and apply that learning to predict the future and incorporate it within our underwriting today. This will give us a far better chance of avoiding the problems of the past. The reality is that we need to exist and thrive in a commercial market where innovation and flair enable the threats to be turned into opportunities. However, this must be done in a controlled environment, as insurers owe it to their customers and shareholders to bring more stability to their results and, therefore, greater security for all.

What have we seen recently?

\section{Justice}

In recent years, we have seen several cases where the courts have created new law to deliver the modern concept of "justice". In a number of instances, this has meant that the definition of "injury" is being challenged and expanded. It has also meant that we have seen cases that have challenged the courts to decide how far the common law duty of care extends. A good example was the House of Lords ruling in the Fairchild case.

\section{Fairchild judgement ${ }^{1}$}

These were several asbestos-related claims involving mesothelioma and more than one defendant. The High Court dismissed the claims on the grounds that the claimants had

\footnotetext{
${ }^{1}$ Fairchild vs. Glenhaven Funeral Services (2002).
} 
failed to prove which of the defendants were responsible for the exposure that led to the condition.

The Court of Appeal rejected the appeal on the same grounds and so the claimants appealed to the House of Lords, the U.K. Supreme Court, but before the case was heard, the government made it clear that it was prepared to legislate if justice was not served on the claimants. The government regarded as unacceptable that asbestos victims should be left uncompensated.

The House of Lords overturned the decision of the lower courts and found in favour of all claimants.

There is no doubt that the Lords were heavily influenced by the unjust nature of the previous rulings and set out to ensure that the compensation was paid. The Lords did attempt to limit the impact of the judgement to the cases only while acknowledging that it may be used as the basis for future decisions, but that such cases must be considered on their individual merits.

The House of Lords found that each defendant's wrongdoing had materially increased the risk of contracting the disease and was sufficient to satisfy the causal requirements for his liability. Accordingly, applying that approach and in the circumstances of each case, the claimants could prove, on a balance of probabilities, the necessary causal connection to establish the defendant's liability. What was the impact?

- The ruling applies only to the proof of causation in mesothelioma claims but is likely to be used by claimant lawyers as a precedent for other diseases or conditions.

- The law of tort exists to provide compensation where it is justified. These cases may be used as a precedent in the future where compensation is deemed to be justified but not necessarily supported by law.

- The situation of being able to recover full damages from a single employer irrespective of the period of exposure is likely to lead to a "deep pocket" approach whereby the employer best able to pay or with the fullest insurance history is the main (and possibly sole) target for claims.

- Lawyers will in future only need to identify one employer to proceed against. Defendant insurers will, therefore, need to identify other culpable parties to bring in under third party proceedings.

- Where medical evidence is unclear, the claimant should not suffer and the benefit of any doubt will be given to the claimant.

There was no change to the burden of proof.

As mesothelioma can develop more than 40 years after exposure to the fibers, claims can fall under policies issued many years earlier and at a time when the underwriter could not possibly have anticipated this interpretation of the law.

\section{Retrospective re-interpretation of legislation}

It is not just the courts ruling on liability that we have to contend with; it can be changes to existing legal interpretations that affect negligence. 
Prior to Shell vs. Jeromson ${ }^{2}$ it was generally accepted that The Asbestos Regulations of 1931 only applied to the asbestos industry. The courts had also accepted this position on a regular basis, the most recent being in 1997. However, in 2001, the Court of Appeal decided that the Regulations applied to the incidental use of asbestos in any industry. This instantly rewrote history and meant that the accepted application of the Regulations was changed some 70 years after their introduction. In other words, a retrospective change of law has, in effect, widened the scope of liability to all industries that used asbestos where they have not complied with the Regulations. The major issue for insurers is that risks have already been accepted on the basis of the original interpretation and they are now faced with potential liabilities that were never envisaged at the time of the writing of the contract.

\section{Vicarious liability}

We have also seen a ruling on the subject of vicarious liability where there has been an expansion to the long-held legal principle of an employer being liable for acts committed by employees in the course of employment.

In the case of Lister and others vs. Hesley Hall Ltd. ${ }^{3}$ the House of Lords decided that acts of sexual abuse committed by the warden of a boarding school were sufficiently connected with his work for them to have been committed within the scope of his employment. The school was therefore vicariously liable for the acts of sexual abuse. This was new law; previously, the vicarious liability of an employer only applied to actions in the course of employment.

The question the House of Lords was addressing was whether as a matter of legal principle the employers of a warden of a school boarding house, who sexually abused boys in his care, may, depending upon the circumstances, be vicariously liable for the torts committed by their employee. Following is some background to the case:

- The school and boarding house were owned and managed by Hesley Hall as a commercial enterprise.

- Children with emotional and behavioural difficulties were sent by local authorities to the school.

- Claimants were resident at a boarding annexe to the school.

- The aim of the boarding annexe was to provide accommodation to help the boys adjust to normal life; it was intended to be a home.

- Hesley Hall employed a warden who, with his wife, was responsible for the day-today running of the annexe.

- Hesley Hall admitted that they were aware of the opportunities for sexual abuse to take place.

- The House of Lords ultimately dealt with the case and found in favour of the claimants.

\footnotetext{
${ }^{2}$ Shell vs. Jeromson (2001).

${ }^{3}$ Lister and others vs. Hesley Hall (2001).
} 
The factors that influenced the decision were:

- The warden was employed specifically to look after the children and act in their best interests, and clearly he had failed to do this. The acts of abuse took place on the premises of the employer during the time he should have been caring for the children.

- The employer had taken the children in with the specific intention of caring for them. The employer had delegated this responsibility to the warden who was responsible for the supervision and running of the house.

The employer was deemed to be vicariously liable on the basis that because the abuse was carried out during the time the warden should have been caring for the children and on the premises provided by the employer, there was such a close relationship between the acts and the employment.

It may now mean that even where the employer has done everything possible to prevent harm, he may still be liable, and effectively it imposes a strict liability upon employers.

Tort law evolves as the attitudes of society change. Liability insurance is inextricably linked to tort law. Without liability insurance, it is doubtful that tort law as we know it would exist for the simple reason that those who have been wronged would be unable to receive the appropriate compensation for their harm. The difficulty for the underwriter is in predicting how social attitudes and the laws that reflect them will change over time. We can be sure, however, that courts will continue to deliver the contemporary concept of justice and may well judge history with the benefit of hindsight, effectively applying the standards of today to acts of the past.

It is not just the liability laws that change but society is also developing views on the circumstances in which compensation should be paid.

\section{Compensation culture}

All too often we see signs that society is increasingly risk averse, with some claims that there is a growing "compensation culture". It is not the industry's aim to enter into a debate on whether such a compensation culture exists, but we do hope to offer pragmatic solutions to dealing with the current trends.

The insurance industry does not seek to impose any views on the type of harm that should be subject to compensation nor does it express any opinions on the appropriate levels of compensation. It does, however, call for any changes to be made prospectively only to ensure that change can be factored into the pricing of individual risks. It also expects policymakers to understand that the widening of compensation laws comes at a price through increased premiums that are usually passed on to society by way of higher prices.

In May 2004, the Better Regulation Task Force published a report entitled "Better Routes to Redress" "which looked at the issue in the U.K. The report considers how

\footnotetext{
${ }^{4}$ Better Regulation Task Force (2004) available at www.brtf.gov.uk.
} 
those with a genuine grievance can secure appropriate redress efficiently and effectively, while ensuring the system is not clogged up by spurious claims.

Launching the report, the chairman of the Task Force said: "It is a commonly held perception that the United Kingdom is in the grip of a 'compensation culture'. Newspapers complain that the U.K. is becoming like the United States with stories of people apparently suing others for large sums of money, and often for what appear to be trivial reasons. In 2000, the cost of litigation in the U.K. as a percentage of GDP was less that a third of that in the U.S. Media reports and claims management companies encourage people to 'have a go' by creating a perception, quite inaccurately, that large sums of money are easily accessible. Over 55 per cent of county court awards in 2002 were for less than $£ 3,000$ ". 5

In 2002, the Institute of Actuaries published the findings of its research ${ }^{6}$ into what it claimed to be a growing compensation culture and stated, in its press release, that this is now costing about $£ 10$ billion a year - or 1 per cent of GDP. This figure is increasing at a rate of 15 per cent a year. The press release went on to state, "In some sectors payments are growing especially rapidly. The police compensation bill is estimated to have more than doubled in three years, from $£ 160$ million in 1997 to $£ 330$ million in 2000 - a sum that represents 7 per cent of the total police payroll. Latest estimates reckon that one in 220 soldiers have made a claim. The total cost of criminal injury compensation in the U.K. in 2000 was $£ 341$ million to 75,000 victims. This is more than all the other member states of the European Union combined". 7

The report also looked at the non-financial costs of the compensation culture. It identified an increase in defensive procedures (e.g. in medicine); lost management time spent assessing risks; and possible worse care and safety as fear of being sued becomes a disincentive to admitting liability or pointing out unsafe practices. Businesses can suffer substantial uninsured losses following a claim, for example:

- to reputation;

- to employee morale;

- by having to replace plant and equipment;

- through lost production time;

- through lost contracts because of failure to meet time commitments.

Lord Levene, Chairman of Lloyd's, has spoken out against what he has called "the cancer" of the U.S. compensation culture spreading to the U.K. and has described Britain as "falling in to the same abyss". He has gone on to describe it as a national economic problem, a tax without representation at the most basic level and has argued that it is growing, with the cost of injury claims rising at 15 per cent per annum.

To return to my original point, clearly, there are widely conflicting views on whether or not a compensation culture exists in the U.K. It doesn't really seem very important

\footnotetext{
${ }^{5}$ Ibid, p. 4.

${ }^{6}$ Institute of Actuaries (2002).

7 Ibid.
} 
The Geneva Papers on Risk and Insurance - Issues and Practice

346

debating whether it exists or not. What is important is to ensure that underwriters keep up to date with what is happening with claims frequency and cost.

\section{Role of claims management companies}

Claims management companies have received much of the blame for the development of a compensation culture in the U.K. These companies advertise extensively on TV, in hospitals and on doctors' appointment cards. Some have representatives in shopping centres and approach people to advertise their services. They operate on a "no win no fee" basis but can charge up to an additional 100 per cent of their fees for successful cases.

\section{The compensation bill}

The Better Regulation Task Force was critical of the way many claims management companies operate and the lack of regulation. The Government responded by giving the industry the opportunity to introduce self-regulation but when nothing emerged, decided to introduce regulation through the Compensation Bill that is currently being debated in the U.K. Parliament. There are, of course, many reputable and highly professional companies within this sector but their reputation has been tarnished through the collapse of the market leaders, the Accident Group and Claims Direct.

The Government has announced that in 2006 it intends to clarify the law on negligence, to make it clear that there is no liability in negligence for untoward incidents that could not be avoided by taking reasonable care or exercising reasonable skill. In other words, they will make it clear that accidents do happen that may not be the subject for compensation. The government has become concerned over reports that organizations such as schools were not undertaking activities such as field trips for fear of being sued should something go wrong. It was thought that this could be having a detrimental effect on the education of children and needed to be addressed. It has also been suggested that some events have been cancelled or not taken place because insurers have forbidden their policyholders to hold them, for example, firework parties. I believe that such claims are exaggerated, but nevertheless they are attractive to the media.

Clarity is to be achieved through the Compensation Bill. The draft Bill was published in November 2005.

\section{The role of lawyers}

The current system in the U.K. is time consuming and expensive; typically a personal injury claim takes 3 years to settle. In many cases, up to 40 per cent of compensation payment is for legal costs (which is too much). This affects policyholders as premiums are driven up as a result and the extra cost has to be passed on to consumers through higher prices for products and services.

Claimant lawyers have been learning from their American counterparts and applying many of the same principles to drive the system forward. 
I fear that U.S. litigation trends are spreading into Europe. My view is that they are being driven by a replication of the social and economic drivers of the U.S. liability system, for example:

- customer-centric propositions;

- service standards for customers;

- the customer is right.

These factors lead to much higher expectations of service and potentially an increased willingness to sue if the promised standards are not delivered. The willingness to sue can be exacerbated by the advertising of the claims management companies. While we favour a customer-centred approach and high standards of service, we fear that encouragement of unrealistic compensation claims does not serve anybody very well.

I sense that a same social/economic environment is developing in Europe and many claims trends are similar.

- Risk awareness leads to compensation awareness - the more people are told of the risks, the greater the level of protection expected. Failure to do so leads to a belief that they have been let down and to an expectation of compensation, whether or not the actual case merits it.

- Compensation for non-pecuniary loss is growing (Austria and Germany have seen rocketing levels).

- Medical liability is a big issue, particularly in France, Germany, Italy and Switzerland. It is also an issue in the U.K., primarily for the National Health Service.

- There is a growing tendency to consider comparative law cross-border.

- A greater role is being played by the European Court of Justice in ruling on compensation claims.

- Harmonization by imposed law (EU) is increasing, heavily influenced by the goals of consumer protection.

- We see pressure building for the removal of "state of the art" defence, and the 1999 review of the Product Liability directive contemplated the introduction of class actions into the EU.

- However, differences remain, for example, fault-based liability versus strict liability, subjective fault (e.g. Austria) and presumed fault (e.g. Spain), and levels of damages awarded.

We are seeing claims brought for a wide range of medical conditions that only a few years ago would never have resulted in a claim being paid.

\section{Psychiatric illness}

One area where we have seen a lot of activity in the courts is the area of psychiatric illness. This has led to a number of claims:

\section{Stress/depression}

Stress is an emotional response to life. For a few individuals, it may give rise to psychiatric illness, whereas for the majority there will be no problem. Stress is the 
body's reaction to pressure, generally when the body is unable to cope with it. A person may be able to cope and even thrive on pressure but once a peak is reached, it can lead to fatigue, exhaustion, ill health and distress. Each person is different and as a result, it is difficult to predict when healthy tension peaks and is replaced by detrimental stress.

Stress may be caused by a combination of factors, for example domestic problems, job insecurity or financial worries. To succeed, a claimant must be able to show to the court that they are suffering from a recognized psychiatric condition caused by workrelated stress.

We did see a significant number of expensive claims arising from the workplace but more recently the Courts have attempted to bring some discipline to the circumstances for claims to succeed by laying down guidelines for work-related stress claims.

The case of Hatton vs. Sutherland ${ }^{8}$ was the most significant development in this area. In this case, the claimant was a teacher in a comprehensive school. She had taken on extra responsibilities in 1993 and was subject to frequent illnesses until she eventually signed off work in 1995 because of depression and never returned.

The Court of Appeal ruled that she had never told anyone that she attributed her absences to overwork. Her workload was no greater or burdensome than any other teacher and her pattern of illness and absence was, on the face of it, attributable to causes other than stress. The Court found that nobody could be blamed and no award was made.

The situation now is that an employer will not be liable unless there is a real risk of breakdown, which the employer ought reasonably to have foreseen, and which he ought properly to have averted.

To succeed, a claimant will have to show that the kind of harm suffered was reasonably foreseeable to that particular person. This may well depend upon the relationship between the employee and the employer and the demands placed upon the employee. Unless the employer has evidence to the contrary, he will be entitled to believe the employee is a person of reasonable fortitude and up to the normal pressures of the job. He will be entitled to take at face value what he is told by his employee about his health or how he is coping with his work, unless he has good reason to believe the contrary. The Court found that there are no occupations that should be regarded as intrinsically dangerous to mental health. It is necessary, therefore, to look at the workload, the intellectual and other demands of the job and whether any of the employees, not just the claimant, are showing symptoms.

There is now a duty upon employees to take responsibility for their own health. If they are suffering problems, they should either bring them to the attention of the employer or find another job.

Equally, employers should not be complacent. They should take reasonable care to avoid placing employees under stress and must not ignore complaints or obvious signs of stress. The Court did comment that employers that offer a confidential advice service with referral to appropriate counselling are unlikely to be found to be in breach of their duty.

\footnotetext{
${ }^{8}$ Hatton vs. Sutherland and others (2002).
} 


\section{Failure to educate}

We have seen claims brought against schools and education authorities for "failure to educate" children, usually when examination results are below expectations. The arguments are that the disappointment suffered is a form of psychiatric injury and the education establishment has a professional duty to the child and its parents.

\section{Fear of asbestos}

Exposure to asbestos can cause a number of different conditions. One that has recently been the subject of litigation is a condition called "pleural plaque", which is scarring of pleural tissue surrounding lungs. There is no detectable impairment or injury but will be found on a chest X-ray. There is a small risk of other diseases in future, giving rise to anxiety, for example, 'fear', a psychiatric condition for which compensation is payable. Claimant lawyers in the U.K. have been touring the industrial areas of the country with mobile X-ray equipment seeking out potential new claimants, a tactic that was introduced to them by U.S. lawyers.

Several insurers brought a test case in early 2005 to challenge (a) whether pleural plaques are actionable and (b) if they are, that the level of awards was too high. This met with partial success: the judge ruled that while the condition itself is not actionable, the anxiety that pleural plaques cause is actionable. However, the judge decided that final awards in these cases should be in the range of $£ 6,000-£ 7,000$, roughly half the conventional sums typically being previously agreed in settlement of these cases. This decision is now subject to an appeal.

\section{Fear of death}

Towards the end of 2005, we had a claim from a mortuary worker who developed a morbid fear of death. She claimed that handling corpses became more difficult over time to the extent that she developed an unhealthy obsession with death that amounted to an illness. Each day spent working in the mortuary made her symptoms of clinical depression and post-traumatic stress disorder worse. She received $£ 15,000$ for the mismanagement of her condition, including $£ 9,000$ for injury to her feelings.

\section{Injury to feelings}

The case of Essa vs. Laing $^{9}$ saw an award for personal injury arising out of unlawful race discrimination.

The claimant was a Welsh international amateur boxer of Somali origin who worked part time as a construction worker. He suffered an incident of severe racial abuse from a foreman and complained, but left his job, as he did not believe his complaint was taken seriously. He alleged the abuse caused him severe depression and a personality change, and he subsequently lost interest in boxing. His tribunal

\footnotetext{
${ }^{9}$ Essa vs. Laing (2004).
} 
proceedings for race discrimination included a claim for personal injury. It was held that the test of reasonable foreseeability did not apply, and the claimant simply had to show that there was a causal link between the discrimination and his loss.

It is of concern that the majority of the court suggested that injury to feelings was akin to psychiatric injury. This is significant, as it will now be argued that injury to feelings fall within the definition of injury in an insurance policy. Furthermore, the majority in the Court of Appeal held that if it was foreseeable that injury to feelings would occur, then it was equally foreseeable that there would be psychiatric injury.

\section{Whiplash}

Whiplash is a soft tissue injury to the neck, effectively a sprain of the neck and usually arises as a result of a motor accident. Treatment is straightforward, usually half a dozen sessions of physiotherapy.

It is a major source of claim, with something like 200,000 claims for compensation per annum, costing the insurance industry more than $£ 750$ million each year. Whiplash claims are the most common type of insured personal injury claims in the U.K. Most sufferers make a very quick recovery; it is rare for claimants to develop chronic symptoms or disability. Generally, the condition is one of temporary discomfort and the award is for the "pain and suffering" of the claimant.

The legal costs associated with these claims can be the same level as for the damages awarded. Given the numbers involved, it makes these claims very expensive for the insurance industry.

It is debatable to what extent there is a genuine injury, but it has become routine for claims arising from motor accidents to include an element for whiplash: it has become an entitlement.

\section{Bodily injury?}

We have seen a number of claims that seek to stretch the boundaries of what constitutes bodily injury. Not all have been successful but are indicative of the extent to which there is greater creativity in the kind of claims that are being made. It is also true to say that the underwriter did not envisage them at the time the policy wording was drafted.

\section{Failure to be made "head girl"}

The parents of a schoolgirl were awarded damages after a claim for injury to her feelings for not being made "head girl" at her school. It was claimed that she had been led to believe that she would receive that appointment and that the decision to appoint another girl had caused her depression and injury to her feelings.

\section{Falling coconut}

Travel agents have to deal with numerous claims a year for alleged personal injury. One such case involved a claim following the falling of a coconut on to the chest of a 
holidaymaker while she was reclining under a palm tree in the Dominican Republic. The claim against the tour operator was settled out of court for $£ 1,700$. She had alleged that it could have been fatal.

\section{Too many letters}

Just before Christmas in 2003, a postman sued a university lecturer for posting too many letters. The postman claimed he had pulled a back muscle after lifting a sackful of journals the lecturer had posted in a normal red pillar-box. This claim failed.

\section{Acoustic shock}

Acoustic shock is the term used to describe a trauma due to exposure to unwanted and sudden bursts of pressure to the ear. It is most common among call centre workers and is the consequence of listening to piercing noises via telephone headsets. Those using conventional telephones can quickly move the phone away from their ear while those using headsets cannot. The call centre employee has an almost permanent exposure to noise.

The noises can be caused by fax machines calling their number by mistake, feedback oscillation from cordless phones or from alarms or whistles blown by people not happy with being called.

The most significant claims activity involved 26 British Telecom switchboard operators who won compensation of more than $£ 250,000$ in an out-of-court settlement in 1999. They suffered acoustic shock from unexplained screeches on telephone lines. One man's injuries were so severe, including hearing loss, constant tinnitus and difficulties with balance, that he was awarded $£ 93,000$.

BT said that the main cause was angry customers shouting or children blowing whistles down the telephone and that since 1991, their headsets have been fitted with noise suppression devices.

\section{Osteo-arthritis}

One of the more recent sources of claims is for osteo-arthritis. It is a condition caused by kneeling too much while working. For many generations, it was generally known as "housemaids knee".

There are also conditions affecting the hand or elbow and all result in pain and tenderness and may include stiffness of the joints.

It is particularly common with miners and construction workers and we are seeing very large numbers of claims being made over the last few years. It is part of a package of claims from ex-miners, including vibration white finger and chronic pulmonary disease, most of whom claim for all of the conditions.

\section{Fraud}

There is an increasing problem with fraudulent claims in the U.K.; it is not limited to liability classes but is a threat to all areas of the industry. 


\section{Claims against local authorities}

In Northern Ireland, there was a housing estate where over 80 per cent of the residents had brought a successful claim against the local authority for trips due to uneven pavements. When this information was brought to the attention of a judge in yet another case, he threw out the claim and made it clear he would be very suspicious of any subsequent claims.

Claims against local authorities for trips on uneven pavements are a major problem in the U.K. For example, the Liverpool Council has received a massive increase in such claims in recent years:

- In 2000, they had 2,200 such claims;

- In 2001, it was 4,000;

- In 2002 , it had risen to 6,000 .

The problem exists for many councils and it has been suggested that as many as 80 per cent of all such claims are false. One man was actually in prison on the date he claimed he had fallen and another apparently files a new claim every year in time for Christmas. One entire family claimed they had been hurt tripping over the same stretch of pavement.

\section{Fraudulent or "stage-managed" claims}

There have been reports of an increasing number of stage-managed claims, especially involving motor vehicles. There have been criminal convictions for gangs acting to extort money from insurers from accidents that did not happen. They would acquire wrecked cars and set up accident sites and claim for personal injuries allegedly suffered.

There was even one case involving a bus that was involved in a minor mishap in leaving the garage, and the number of people coming forward to claim, alleging they were passengers, was actually more than the bus was physically capable of holding.

\section{Silicosis}

A recent court case in the U.S. questioned the validity of claims for the lung disease silicosis, a debilitating and potentially fatal illness. A U.S. federal judge criticized the law firm representing 4,256 people who had filed silicosis suits against various companies, claiming that "These cases were driven by neither health nor justice" and "were manufactured for money". While she did not dispute the existence of the disease, she questioned the medical evidence for these particular claims, and noted that silicosis claims filed in Mississippi courts jumped from 40 five years ago to 7,228 in 2003.

\section{The ever-expanding boundaries - and how to deal with them}

We can expect further cases to continue to test the boundaries of what are and are not acceptable claims. For this reason, we must expect that the next 30 years will bring as 
many changes as the last 30 . Liability laws will also continue to be challenged as new causes of claim or new sources of perceived injustice are brought before the courts to rule upon. The challenge for insurers is how to cope with the trends, including the retrospective impact of change on IBNR (Incurred But Not Reported) and other claims in the pipeline.

What may have been unthinkable only a few years ago may well become a routine claim for which compensation will be paid. There is no doubt in my mind that the expectations from society are changing and this shift influences policymakers. We have also seen a shift in thinking by judges who are increasingly persuaded by consumer protection issues.

The U.S. style to litigation is spreading to Europe and the Wall Street Journal recently carried a story reporting that, "Plaintiffs lawyers, long the scourge of big business, are facing serious obstacles in the U.S. New laws are capping damages and making it harder to move cases to friendly jurisdictions. Now, some of the biggest names in the plaintiff's bar have a new strategy: Hunt for plaintiffs in Europe". ${ }^{10}$ Countries that have yet to experience these developments really should take note because the probability is that the trends will gradually spread further, with EU Member States particularly vulnerable.

Insurers have paid a heavy price with long-tail liabilities and will continue to do so unless a more sensible basis of underwriting these risks is adopted. In countries such as France, the lessons have been learned and claims-made triggers adopted. It is difficult to do so in the U.S.A. because of the regulatory requirements and the political influence of the State insurance officials but this is not the case for General Liability (GL) policies in the U.K.

Insurers seem determined to retain traditional losses occurring policy wordings, despite the fact they were never designed for the type of claims we face today and are wholly inappropriate as a means of providing security. These reasons are probably based upon a fear of losing market share or hitherto profitable business.

How a policy is actually triggered is something that I find a surprising lack of knowledge about in the market. There seems to be a common expectation that a GL policy triggers in the same way as for Employers' Liability (EL).

EL claims are shared between insurers on a time-exposed basis. This is because an EL policy covers "injury caused during the Period of Insurance" and the cause of, for example, asbestos diseases is the exposure to asbestos.

A GL policy is different; it covers "injury or damage happening during the Period of Insurance". The date the injury or damage happens is not necessarily the same as when it is caused. The mere exposure to asbestos does not automatically lead to a disease; many people are exposed because it is in the air but only a small proportion become ill. Therefore, mere exposure cannot meet the requirement for the injury to happen during the policy period.

For a GL policy to be triggered, the injury or the damage has to happen during the Period of Insurance. This is not always straightforward; in the case of an accident, it generally raises no problems but for latency claims, difficulties can arise. For example,

\footnotetext{
${ }^{10}$ The Wall Street Journal (2005).
} 
in cases of mesothelioma, the date the injury happens is when irreversible cell damage occurs which, according to leading medical specialists, tends to be approximately 10 years prior to diagnosis. To illustrate this point, a claim where the condition was diagnosed in 2005 should be brought under the policy in force in 1995, as this is the date the injury happened. This was the conclusion reached in the case of Bolton Metropolitan Borough Council vs. MMI and Commercial Union 2005 and is entirely consistent with known case law and medical opinion. This means that there may be uncertainty for policyholders in many instances because latency claims can vary in many ways and it begs the question of "just how valuable are losses occurring wordings". In many instances, the imagined benefit will not exist. In any event, trying to rely upon a policy issued many years earlier presents a number of problems in itself, not least being tracing the policy and the adequacy of the limit of indemnity. As recently as the 1970 s, many policy limits were as low as $£ 250,000$.

For insurers, long-tail liabilities present some significant problems. Apart from coping with the cost of legacy claims, insurers need to be able to price the business they are writing today but will be the future source of claims. In order to price accurately, insurers must be able to assess the likely frequency and severity of claims. This is virtually impossible for claims with a long latency.

In 1971 when the U.K. government was in the throes of introducing compulsory insurance requirements for Employers' Liability, one of the issues was the financial limit on the minimum level of insurance required. It decided that $£ 2$ million was an appropriate amount, based upon the fact that claims for even $£ 1$ million were difficult to imagine and that $£ 2$ million simply could not happen. In 2005 , we are looking at settlements of $£ 15$ million or more for very serious injury cases. These cases take time to settle; a similar accident happening today may not be settled until, say, 2012, so what will be the equivalent value at that time?

Over a long period, it is impossible to predict wage inflation, social inflation, inflation in the cost of care as well as increases in court awards. It is also impossible to predict the advances in medical science that will occur over such a period. This may act to the benefit or detriment of the insurer in terms of finding a cure or carrying out a more accurate diagnosis. Any medical development that prolongs the life expectancy of a claimant will increase the cost of the claim. Equally, we have to consider what changes are made to the law or how the law is interpreted.

The argument put forward by policyholders is that a loss occurring basis gives businesses much more insurance cover than might otherwise be the case. I agree with this to an extent but there is uncertainty. I would add that insurers are anxious to avoid a repeat of history and are now much more cautious with regard to new and emerging risks, often due to the influence of reinsurers. In many cases, it has been the reinsurance industry that has borne the major share of the long tail and it is now much more cautious about those they will reinsure and the basis for providing reinsurance. They are risk managing their business in the same way that direct insurers need to; it is not just something for policyholders to do.

Market capacity for pharmaceutical risks has fallen dramatically. There is speculation over the safety of mobile phones, EMF, GMOs and nanotechnology. There is concern about the effects of BSE, passive smoking and silica. Child abuse is a growing source of expensive claims, with sums in excess of $£ 1$ million being sought in 
individual cases. We are seeing more and more exclusions appearing in wordings and with the cost of claims continuing to rise, policyholders will be asked to pay more in premiums for less cover.

These exclusions anger our policyholders but it is because of the losses occurring wording that exclusions are needed. I expect to see more exclusions being introduced to combat the damaging effects of long-tail liabilities. Alternatively, claims made coverage could be a way of maintaining wider cover because it is possible for insurers to respond to claims trends, new laws and legal precedent quickly and adjust their terms accordingly. Sooner or later insurers will have to respond to the threats posed by the unknown and unquantifiable exposures that will come back to haunt them many years later.

\section{The 21st century liability insurer}

The insurer for the 21 st century needs to be much smarter than the 19th and 20th century versions and exploit both the knowledge and the technology we have today. I firmly believe that the issues described can be dealt with successfully. We are not talking about a monster that is out of control.

For the underwriter of the 21 st century, many of the challenges faced are the same as the underwriter from the 1970s. What is different however is that we have much more experience of what can go wrong; we know there will be changes to the law and how it is interpreted; we know there will be new causes of loss.

The 21 st century insurer must apply the learning experience and underwrite in a very structured and controlled way:

- Use only the most experienced, skillful and talented liability underwriters. The insurer should make the very best use of these talents, including the coaching of less experienced underwriters to preserve the intellectual capital within the organization for future use;

- Empower underwriters only to write business within their sphere of proven competence;

- Apply portfolio management techniques, which means that every transaction can be monitored and responded to swiftly should the need arise;

- Have very clearly stated and defined risk appetite and stick to it, do not go further in pursuit of market share;

- Ensure that underwriters, actuaries and claims managers work very closely on all aspects of the business, including portfolio pricing;

- Employ environment scanning practices to ensure that every legal, scientific, technical and social shift is identified and its impact factored into underwriting and claims management;

- Only issue policy wordings that can be truly understood and control the exposure to within predictable levels;

- Reward good risk management and penalize the bad one. This provides real incentives to businesses and can be far more readily achieved with tighter wordings that achieve predictable outcomes. 
There will always be uncertainty, which is what insurance is about. The successful insurers for the future will be those that risk manage their own risks effectively and can provide the price stability desired by policyholders and remove the result volatility detested by shareholders. It can be achieved through a controlled and disciplined way of transacting business that will enable insurers to take the changes in their stride and preserve cover that policyholders will need for new and emerging risks.

\section{Conclusion}

We have seen that courts will increasingly interpret the law to ensure that the modern concept of "justice" is delivered and that this will serve to encourage claimants to test the boundaries of what a court will and will not accept. In particular, we can expect to see the area of psychiatric illness present regular challenges.

Undoubtedly, the world of litigation for bodily injury has changed for good and liability underwriters must accept this and adapt their underwriting accordingly. Keeping pace with developments and anticipating future trends will be crucial in achieving acceptable underwriting results. With claims costs rising at least with the pace of inflation, premiums will need to rise to keep pace with them and all new sources of liability potentially add to the burden.

Perhaps the biggest challenge of all is for liability underwriters to accept that there is a need for strong underwriting discipline, a clear focus on risk appetite and risk management and for policy wordings to clearly reflect and control the exposure the underwriter thought he was accepting. Clearer policy wordings and more stable results actually offer the policyholder a better deal through more predictable prices, greater clarity of cover and a stronger, more competitive market.

\section{References}

Better Regulation Task Force (2004) Better Routes to Redress, pp. 1-48, available at www.brtf.gov.uk.

Essa vs. Laing Ltd. (2004) ICR 746.

Fairchild vs. Glenhaven Funeral Services (2002) 3 WLR 89, 3 All ER.305 (HL).

Hatton vs. Sutherland and others (2002) EWCA Civ 762 All ER 1; [2002] ICR 613.

Institute of Actuaries (2002) The Cost of Compensation Culture, available at www.actuaries.org.uk.

Jeromson and Dawson vs. Shell Tankers (U.K.) (2001) PIQR P.265. Court of appeal (Civil Division) [2001] ICR 1223.

Lister vs. Hesley Hall Ltd. (2002) 1 AC 215, [2001] 2 WLR 1311.

The Wall Street Journal (2005) 'Courting abroad: For the tort bar, a new client base: European investors', The Wall Street Journal (2nd September).

\section{About the Author}

Phil Bell Joined Royal \& Sunalliance in 1968 and has specialised in liability insurance since 1974. He now has specific responsibility for underwriting the complex cases within the U.K., managing major technical issues and negotiates the reinsurance Treaty. At industry level, he is a member of the ABI Liability Committee and is also Chairman of the CEA General Liability Committee. Within these roles, he has been involved in a wide number of major industry issues. 